\title{
LIFE, ILLNESS, DEATH: THE RED FLOWERS OF OUR EXISTENCE
}

\author{
Renata Martinec $^{1}$ \\ ${ }^{1}$ Faculty of Education and Rehabilitation University of Zagreb, Department for Motor \\ Disturbances, Chronic Disease and Art-therapies, Borongajska cesta 83f, 10000 Zagreb, \\ Croatia
}

„... There's no chance for us It's all decided for us

This world has only one Sweet moment set aside for us Who wants to live forever?

... But touch my tears with your lips Touch my world with your fingertips And we can have forever And we can love forever Forever is our today..."

(May, B., 2011)

Elevator. I stood opposite my neighbor. Silence. Tears. "He has a brain tumour." Silence again. "He" is his son. We looked at each other. I could feel his fear. I felt his fear in my chest. In my whole body. I started to talk. Only nonsense. About some people that I know and who still have lived after the same diagnosis. About hope, miracles, fight. Only nonsense.

So many things have happened through human history. So many achievements in medicine, culture, arts and technology. But do we have more wisdom regarding illness and death in relation to our ancestor. Probably not. And also, we still do not know how to get out of the trap of giving weak comfort. However, nowadays we are looking for aging gene, the secret of eternal youth, immortality, diseaseless, etc. On the other hand, there is an elevator from the beginning of this text. With eternal questions associated with mortality and suffering. All of these are personal issues that cannot wait for the magic outcomes. In that moments everyone is seeking their own salvation with the help of medicaments, nature, spirituality, religion, philosophy, or transcendence.

\footnotetext{
1 Correspondence to:

Renata Martinec' Faculty of Education and Rehabilitation University of Zagreb, Department for Motor Disturbances, Chronic Disease and Art-therapies

E-mail: renata.martinec@erf.unizg.hr
} 
Sometimes there is also a hope that, in the meantime, a revolutionary way of curing will be found that will save us. And set us free from pain, disability, decline and dying.

Fortunately, today we are witnessing great progress in various areas of human achievements, especially in the field of biomedicine and different kind of technology. Their current results are very promising. But, are they enough to us in our effort to understand the essence of life, illness and death? And also, to understand the mechanism of recovery. Of course that we need something more. We need the idea of renewal, emotions, communion, empathy, trust and dignity. So, can various scientific disciplines and spiritual orientations get start together to dance a tango? To help us to sustain a passion for life. Even when we are weak and helpless. Or we can paraphrase Sabina Bryan who pointed out that we can do anything as long as we have the passion, the drive, the focus, and the support (Bryan. 2021).

Among so many unanswered questions, there are still a few, maybe the oldest. What is the reason for illness and death? What is the reason for decay and disappearance? Why we have to suffer? There are plenty of theories and deliberations defined with the aim to clarify the causes of human suffering. According to them, possible causes could be attachments, expectations, dissipation, desire, lack of discipline, physical discomfort, unpredictability, life's injustices, ignorance, etc' (Kundu, 2021.). Or, as Buddha identified, it could be third type of suffering - "life's inherent unsatisfactoriness due to its intrinsic instability" 4 . We can conclude that there is no unique answer. And also, how all these deliberations can help person who is chronic or terminally ill? Sometimes, all these ancient and contemporary thoughts are inspiring, sometimes too demanding in their interpretations. Anyway, they are not universal for everyone. That means that every person should find own way of coping with illness. In that sense, Friedrich Nietzsche has nicely emphasized that living means suffering, surviving means finding meaning in suffering (Nietzsche, 2007).

Many religious, philosophical or spiritual concepts point out that different kind of human suffering should be understood as a sign or signal that we have to change something in our life. It could be lifestyle, worldview, priorities or value system. Illness may be our teacher who encourages us to learn something new about ourselves. Or about matters above us, like cosmic, universal or divine principles. Illness also teach us about hope, struggle and perseverance. Charles Dickens probably thought similarly when he wrote: "Suffering has been stronger than all other teaching...I have been bent and broken, but - I hope - into a better shape." (Dickens, 2018)

But ironically, although we have not came up the answers related to some important health and life issues we still have a dream of immortality, eternal youth and unconditional excellent health. However, we don't doubt too much whether it would be a damnation or an ultimate satisfaction. To know that something has no end can be frightening. How immortality may be frustrated tried to explain a famous imaginary character, Louis, in the book "Interview with the Vampire" when he said: "Immortality holds as much sadness and loss - perhaps even more - than mortality." (Rice, 2007). Maybe, these days our effort should be directed to life extension and healthier lives (Tniman, 2012). In this concept, positive principles and achievements triggered by the idea of transhumanism can be helpful. On that way, development of biomedical, technical and technological sciences is condition sine qua non, 
but also we shouldn't forget human mind as well as transcendental and emotional dimension of our being.

Regarding contemplative state of mind Langer et al. cited that contemplative meditative experience can induce de-identification from the static self which can results with "a greater degree of psychological flexibility and a more genuine way of seeing the world, leading to a new perception of the self that is connected to an experience of freedom, and contributes to one's own well-being, as well as to that of others and of the environment. "(Langer at al. 2017).

Perhaps we should conclude that we must strive for scientific endeavors but also we have to strive for love, truth, beauty and goodness. In fact, we need to seek for everything that our life can make richer and more fulfilling. In that effort of understanding our transience we may discover the beauty of our life, its purpose, and the reasons why something is happening. And then - life, illness, and death would become the red flowers of our existence. In that beautiful garden where eternal and divine as well as mortal and human can meet each other. Together with anything else that is needed in that magnificent process of spinning and supporting the whole life cycle.

\section{REFERENCES}

1. May, B. (2011). "Who Wants to Live Forever", "Queen Greatest Hits II", Hollywood Records Inc.

2. Bryan, S. (2021). BrainyQuote.com. Retrieved February 15, 2021, from BrainyQuote.com at https://www.brainyquote.com/quotes/sabrina_bryan_611182

3. Kundu, S. C. (2021). What are the Cause of Suffering? Retrieved February 28, 2021. at https://www.researchgate.net/post/What_are_the_causes_of_suffering

4. Nietzsche, F. (2007). On the Genealogy of Morality, Cambridge University Press, New York.

5. Dickens, C. (2018). Great Expectations, Create Space Independent Publishing Platform, USA

6. Rice, Anne (2007). Interview with the Vampire, Buccaneer Books Inc., USA

7. Tniman, J. (2012). Some Brief Thoughts On Immortality. Bodyfuturist / exploring the legal and philosophical issues of emerging technology. Retrived March 14, 2021. at https://boydfuturist.wordpress.com/2012/08/24/some-brief-thoughts-on-immortality/

8. Langer, AI., Schmidt, C., \& Krogh, E. (2017). Mindfulness Meditation and the Perception of Beauty: Implications for an Ecological Well-Being. In: MP Levine (Eds.), Perception of Beauty. IntechOpen, London, 207-223. 